\title{
Evaluation of Mathematical Models in Nitrogen Transfer to Overland Flow Subjected to Simulated Rainfall
}

\author{
Meixiang Xie ${ }^{1,2}$, Zhanyu Zhang1,2*, Pingcang Zhang ${ }^{3}$ \\ ${ }^{1}$ College of Water Conservancy and Hydropower Engineering, Hohai University, Nanjing, China \\ ${ }^{2}$ College of Agricultural Engineering, Hohai University, Nanjing, China \\ ${ }^{3}$ Changjiang River Scientific Research Institute, Wuhan, China
}

Received: 6 December 2018

Accepted: 28 March 2019

\begin{abstract}
Nitrogen $(\mathrm{N})$ transfer to runoff contributed to nutrient loss and water pollution. Experiments were conducted to study the ammonia nitrogen $\left(\mathrm{NH}_{4}-\mathrm{N}\right)$, nitrate nitrogen $\left(\mathrm{NO}_{3}-\mathrm{N}\right)$ and total nitrogen $(\mathrm{TN})$ transfer from loam soil to runoff in response to various rainfall intensities (RIs) $(0.4 \pm 0.02,1.0 \pm 0.04$, and $\left.1.8 \pm 0.11 \mathrm{~mm} \mathrm{~min}^{-1}\right)$ and slope gradients (SGs) $\left(5^{\circ}, 10^{\circ}, 15^{\circ}\right.$ and $\left.20^{\circ}\right)$. A typical mathematical model based on effective mixing depth $\left(\mathrm{h}_{\mathrm{m}}\right)$ and a refined model which replaced the time-average $\mathrm{h}_{\mathrm{m}}$ in this typical model with a time-increasing $h_{m}$ were both applied to predict $\mathrm{N}$ transfer to runoff. These models were verified with experimental data to evaluate the applications in simulations of surface $\mathrm{N}$ dynamics. $\mathrm{NH}_{4}-\mathrm{N}$ and $\mathrm{TN}$ concentrations in overland flow presented large deviations but $\mathrm{NO}_{3}-\mathrm{N}$ concentration highly declined from the initiation of runoff and then stabilized with slight deviations. The effective mixing depth deduced from fitted results coincided positively with RI but negatively with SG. The linear regressions between model prediction and experimental results revealed better agreements for $\mathrm{NO}_{3}-\mathrm{N}\left(r^{2}=0.696\right.$; Slope $\left.=1.1617\right)$ than $\mathrm{NH}_{4}-\mathrm{N}\left(r^{2}=0.2538\right.$; slope $\left.=0.7916\right)$ and $\mathrm{TN}$ $\left(r^{2}=0.224\right.$; slope $\left.=0.6658\right)$. The refined model showed improved performance compared with the original model for the $\mathrm{NO}_{3}-\mathrm{N}\left(r^{2}=0.8267\right.$; slope $=0.9996$; intercept $=-0.2675$ versus $r^{2}=0.696$; slope $=1.1617$; intercept $=-0.0438)$.
\end{abstract}

Keywords: nitrogen transfer, overland flow, effective mixing depth, time-increasing hm, rainfall, slope gradient

\section{Introduction}

The chemical transfer from soil to runoff leading to nutrient loss of sloping farmland has been recognized

*e-mail: zhanyu_hhu@163.com as a major threat to soil fertility and receiving water bodies [1-3]. There is most concern regarding nitrogen (N) transfer, as it is increasingly applied to boost crop yields producing eutrophication in surface waters [4, 5]. Accordingly, many field, laboratory and modeling works have been undertaken in an attempt to investigate $\mathrm{N}$ loss and transfer via overland flow and propose mitigation methods $[5,6]$. 
It is widely proved that the $\mathrm{N}$ loss of sloping farmland via overland flow is correlated with rainfall intensity (RI), slope gradient (SG), soil property, and fertilizer application [5, 7-10]. However, most of these studies only analyzed the total $\mathrm{N}$ loads but not the $\mathrm{N}$ dynamics through time. Armstrong et al. [5] reported that total nitrogen $(\mathrm{TN})$ transfer was variable between repeats, and discharge, time of outflow, sediment concentration, slope gradient and sediment size were all dominant influential factors over nutrient transfer by means of simulated laboratory experiments. Yuan et al. [11] pointed out that $\mathrm{NO}_{3}-\mathrm{N}$ (up to $83.1 \%$ in various nitrogen species) accounted for the largest percentage of TN. Wang et al. [12] showed that the nitrate nitrogen $\left(\mathrm{NO}_{3}-\mathrm{N}\right)$ transfer highly decreased at the early stage of overland flow.

Chemical transfer in runoff with the effects of factors mentioned above has been described by models from empirical formula based on monitored field data to physically and chemically based descriptions [13], and these mathematical models are applied to address a wide range of environmental and water resources problems. The processes for chemical transport towards runoff are complex, especially for field nutrient loss to water bodies. In the early developed models with an assumption of an effective depth of interaction (EDI), within which the mixing of soil, rainfall and runoff was uniform and equal to that at the soil surface [14]. Steenhuis and Walter [15] assumed that rainwater mixed completely within a thin zone of surface soil and water. Ahuja et al. [16] conducted experiments by placing ${ }^{32} \mathrm{P}$ as a tracer on the soil surface and at $5-\mathrm{mm}$ intervals in soil boxes. They reported that the rainfallrunoff-soil interaction was greatest on the surface and declined rapidly with soil depth under free infiltration and saturated soil water conditions. Additionally, the EDI increased along with time in the early stage of rainstorms in their study. A non-adsorbed soluble chemical, Br, was later released from soil box to runoff to examine the concept of EDI, and most of $\mathrm{Br}$ was lost during the first 5 min by means of infiltration and runoff [17]. Ahuja and Lehman [18] measured the effects of variable infiltration rates on the $\mathrm{Br}$ transfer to runoff. A nonuniform mixing model considering the effects of infiltration on chemical transfer before and after runoff initiation [18] was proposed by Ahuja [19]. The model using a time-averaged EDI showed practical predictions for $\mathrm{Br}$ transfer in soil boxes to runoff despite the assumed EDI increase with time. Yang et al. [20] described a function between mixing depth and time based on the Kostiakov infiltration equation subjected to water scouring. Yang et al. [3] described a refined incomplete-mixing model for potassium transport to runoff proposed by Wang and Wang [1] by introducing Philip's [21] infiltration formula under unsaturated conditions. The significantly positive relationships between the parameters of the model and SGs and RIs were established. Several studies also reported that the EDI increased with increasing SG [22, 23].
Experimental chemical transfer to runoff simulated by these models typically declined exponentially with time during the initial stage of overland flow initiation $[2,24$, 25], and model performance showed a good agreement with the observed data [26]. Wang et al. [12] found that model performance of soluble phosphorus transfer under water scouring was better than $\mathrm{NO}_{3}-\mathrm{N}$. Still, there have been remarkably few studies on modeling of nitrogen as a primary kind of nutrient for arable lands transfer to runoff under rainfall.

Both $\mathrm{N}$ dynamics from experiment and mathematical modeling must be available to have a better understanding of dissolved $\mathrm{N}$ transfer of sloping farmland to runoff. In the current study, we conducted simulation experiments with various RIs and SGs to investigate dissolved ammonia nitrogen $\left(\mathrm{NH}_{4}-\mathrm{N}\right)$, nitrate nitrogen $\left(\mathrm{NO}_{3}-\mathrm{N}\right)$ and total nitrogen $(\mathrm{TN})$ transfer to runoff. We also applied the effective mixing model [19] to our experimental results and refined the model by replacing the time-averaged effective mixing depth with a time-dependent one. The accuracy of predictions of these models were assessed using $\mathrm{N}$ concentration data from the laboratory experiments.

\section{Material and Methods}

\section{Experimental Design and Set-Up}

We focused on the transfer of dissolved nitrogen to runoff when an excess of infiltration was the main contributor to the overland flow during rainfall from the purple sloping farmland in China.

The predominant laboratory experimental device (Fig. 1) was soil tanks and a rain simulator equipped with nozzles, water pump, and computer terminal. The soil tanks were utilized with the following dimensions:

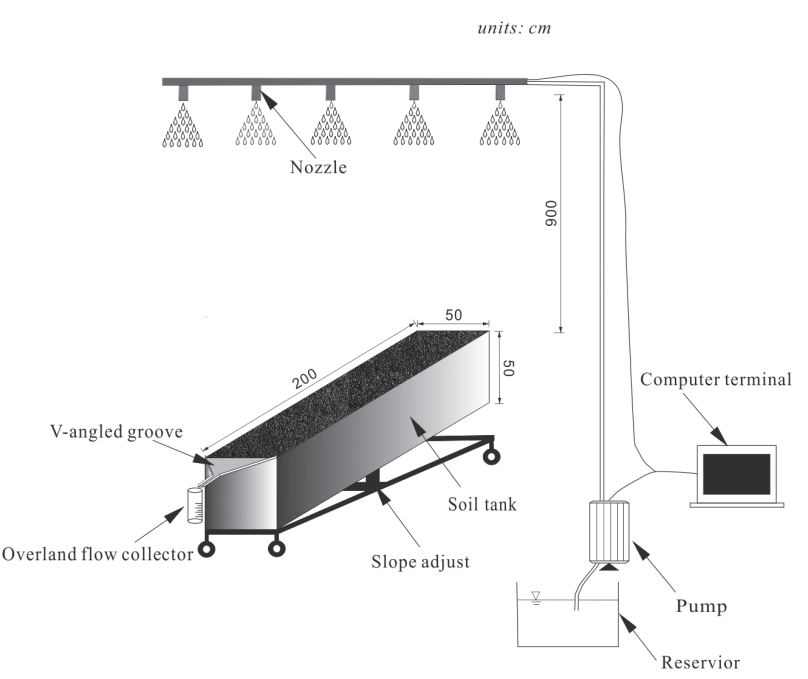

Fig. 1 Schematic diagram of the experimental set-up. 
$2 \mathrm{~m}$ in length $\times 0.5 \mathrm{~m}$ in width $\times 0.5 \mathrm{~m}$ in height. The bottom of the soil tank was paved with a $10-\mathrm{cm}$ cement layer to imitate the bedrock under the purple soils. An amino-plastic web was encased to the walls of the tank in order to prevent boundary effects. The slopes of the soil tanks could vary from $0^{\circ}$ to $30^{\circ}$ via hydraulic pressure slope adjustment. A $\mathrm{V}$-angled groove was set at the end of the soil tank to collect runoff flow. Rainwater in the reservoir could be transported by water pump and then to fall through 9-m height nozzles from the soil surface with $85 \%$ degree of homogeneity of rainfall. The RIs were controlled by the computer terminal.

The soil used in our laboratory experiments were collected from the top $40 \mathrm{~cm}$ soil layer of sloping farmland at the small Wangjiaqiao watershed $\left(110^{\circ} 42^{\prime} \mathrm{E}\right.$, $\left.31^{\circ} 5^{\prime} \mathrm{N}\right)$ in Zigui County, Yichang City, Hubei Province, China. Rainfalls happened intensively from June to September as a result of the regional sub-tropical monsoon climate. The general slope gradients of the local area are from $5^{\circ}$ to $20^{\circ}$. Hence, twelve scenarios were designed, and all scenarios were performed in duplicate. Additionally, fresh soils were used for each scenario. Three RIs $\left(0.4 \pm 0.02 \mathrm{~mm} \mathrm{~min}^{-1}, 1.0 \pm 0.04\right.$ $\mathrm{mm} \min ^{-1}$ and $1.8 \pm 0.11 \mathrm{~mm} \mathrm{~min} \mathrm{~m}^{-1}$ ) and four SGs (5。, $10^{\circ}, 15^{\circ}$ and $20^{\circ}$ ), according to local rainfall and geomorphological features, were designed respectively to study the effects of rainfall intensity and slope gradient on our model and $\mathrm{N}$ transfer to runoff. Each RI was calibrated by tests before rainfall simulations.

Selected physical and chemical properties of the experimental soil are listed in Table 1. This purple soil is classified as loam and entisol according to USDA taxonomy. The soil samples were air-dried and then passed through a $10-\mathrm{mm}$ sieve to remove coarse rock and debris. Then the soils were backfilled into the soil tank in $5-\mathrm{cm}(67.5 \mathrm{~kg})$ increments and compacted to achieve a dry bulk density of $1.35 \mathrm{~g} \mathrm{~cm}^{-3}$. In total, 8 soil layers were backfilled in the tanks. $15 \mathrm{~g}$ urea was dissolved in $40 \mathrm{~L}$ water and sprayed evenly at the soil surface and the soils in the tank were moisturized to achieve certain initial water content (about $0.25 \mathrm{~cm}^{3} \mathrm{~cm}^{-3}$ ) one day before rainfall. Each simulated rainfall duration was $60 \mathrm{~min}$. During the experiments, the overland flow was collected in 500-mL beaker in 1 2 min intervals at early stage of the outflow for $10 \mathrm{~min}$ and $4 \sim 5 \mathrm{~min}$ intervals when flow was stable for the last $50 \mathrm{~min}$. The collected water samples were left to stand and supernatant liquid was saved into clean polyethylene bottles at $4^{\circ} \mathrm{C}$ in a refrigerator. The concentrations of $\mathrm{NH}_{4}-\mathrm{N}, \mathrm{NO}_{3}-\mathrm{N}$ and TN were determined via SmartChem Discrete Auto
Analyzer (SmartChem 200, Alliance, France) within 48 hours.

\section{Theory and Model}

To assist in the interpretation of $\mathrm{N}$ loss to runoff from sloping farmland, we analyzed the experimental data using the model developed by Ahuja [19]. This effective-mixing model is based on the assumption that rainfall and runoff water mixed completely with soil solution within a certain fixed effective soil depth. This thin zone at soil surface undergoes desorption and mixing related to the chemical transportation toward overland flow, and the mass conservation equation is:

$$
\frac{d\left(h_{m} C\left(\theta_{s}+\rho_{s} k\right)\right)}{d t}=-R C
$$

...where $h_{m}$ is the effective mixing depth (cm), $C$ is the chemical concentration in overland flow ( $\left.\mathrm{mg} \mathrm{L}^{-1}\right), \theta_{s}$ is the saturated water content $\left(\mathrm{cm}^{3} \mathrm{~cm}^{-3}\right), \rho_{s}$ is the soil density $\left(\mathrm{g} \mathrm{cm}^{-3}\right), k$ is the soil adsorption rate $\left(\mathrm{cm}^{3} \mathrm{~g}^{-1}\right)$, $R$ is the rainfall intensity $\left(\mathrm{cm} \mathrm{min}^{-1}\right)$, and $t$ is the runoff time (min).

The adsorption-desorption process can be represented by a proportional relationship using linear adsorption isotherm [1]:

$$
C_{s}=k_{l} C_{0}
$$

...where $C_{s}$ is chemical concentration in the adsorbed phase on soil particles ( $\mathrm{g} g-1), k_{l}$ is the isothermal adsorption coefficient $\left(\mathrm{cm}^{3} \mathrm{~g}^{-1}\right)$, and $C_{0}$ is the concentration in soil solution $\left(\mathrm{g} \mathrm{mL}^{-1}\right)$.

Combined with application of Philip's infiltration equation [21] to the infiltration and runoff process to refined model expressed by Yang et al. [3], this model can be outlined as follows:

$$
C(t)=C_{0} \exp \left[-\frac{\left(t-t_{p}\right) R}{h_{m}\left(\theta_{s}+\rho_{s} k_{l}\right)}\right]
$$

...where $C_{0}$ is the initial chemical concentration in soil water within the effective mixing depth $\left(\mathrm{mg} \mathrm{L}^{-1}\right)$ and $t_{p}$ is the water ponding time (min).

Although Ahuja [19] pointed out that effective mixing

\begin{tabular}{|c|c|c|c|c|c|c|c|c|}
\hline \multirow{2}{*}{ Testing soil } & \multirow{2}{*}{$\begin{array}{l}\text { Bulk density } \\
\qquad\left(\mathrm{g} \mathrm{cm}^{-3}\right)\end{array}$} & \multirow{2}{*}{$\mathrm{pH}$} & \multicolumn{3}{|c|}{$\begin{array}{l}\text { Nitrogen content } \\
\quad\left(\mathrm{mg} \mathrm{Kg}^{-1}\right)\end{array}$} & \multicolumn{3}{|c|}{ Particle size distribution (\%) } \\
\hline & & & $\mathrm{NH}_{4}-\mathrm{N}$ & $\mathrm{NO}_{3}-\mathrm{N}$ & $\mathrm{TN}$ & $\underset{(>0.05)}{\text { Sand }}$ & $\begin{array}{c}\text { Silt } \\
(0.002 \sim 0.05)\end{array}$ & $\begin{array}{c}\text { Clay } \\
(<0.002)\end{array}$ \\
\hline Purple soil & $1.32 \pm 0.02$ & $7.8 \pm 0.2$ & $34.58 \pm 3.90$ & $2.86 \pm 0.66$ & $1107 \pm 86$ & $54.72 \pm 2.57$ & $40.19 \pm 2.09$ & $5.09 \pm 0.48$ \\
\hline
\end{tabular}
depth $\left(h_{m}\right)$ increased with time, a time-averaged $h_{m}$ was

Table 1. Selected physical and chemical properties of the soil. 
used in this model for discussing the characteristics of solute transfer to runoff. Meanwhile, during the process of simulation, we found that $h_{m}$ was a critical factor influencing the runoff chemical concentration curves, especially at the early stage of the overland flow. Hence, we adopted a refined model, in which the assumed time-averaged $h_{m}$ is replaced by a time-dependent $h_{m}$. The time-increasing $\mathrm{h}_{\mathrm{m}}$ was in accordance with the increasing effective depth of interaction (EDI) applied in the model of Donigian et al. [14]. This substitution predicts a positive relationship indicated in the study of Ahuja [19] between $h_{m}$ and time:

$$
h_{m}=h_{0}+h_{n} \ln \left(\frac{t-t_{p}}{t^{\prime}}+1\right)
$$

...where $h_{0}$ is the initial effective mixing depth $(\mathrm{cm})$, $h_{n}$ is basic mixing depth parameter $(\mathrm{cm})$, and $t^{\prime}$ is the duration of rainfall (min). Eqs. (3) and (4) can be combined to give:

$$
C(t)=C_{0} \exp \left\{-\frac{\left(t-t_{p}\right) R}{\left[h_{0}+h_{n} \ln \left(\frac{t-t_{p}}{t^{\prime}}+1\right)\right]\left(\theta_{s}+\rho_{s} k_{l}\right)}\right\}
$$

\section{Statistical Analysis}

Model performance was evaluated by means of classical measurements of good of fit, the root mean square error (RMSE) as:

$$
R M S E=\sqrt{\frac{\sum_{i=1}^{n}\left(p_{i}-o_{i}\right)^{2}}{n}}
$$

...where $n$ is the total number of data points, $p$ is a given simulated data point and $o_{i}$ is the corresponding experimental data point. It needs to note that the optimal value for RMSE was 0 .

Additionally, the linear regressions between the measured and simulated data were conducted using Excel (Microsoft Corp., WA, USA) and Origin 8.5 a)

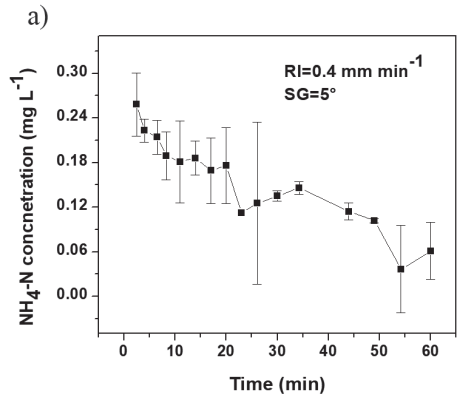

e)
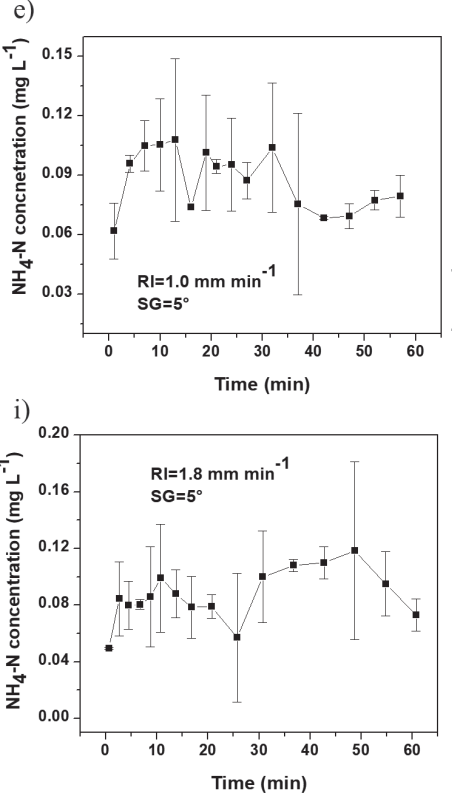

b)

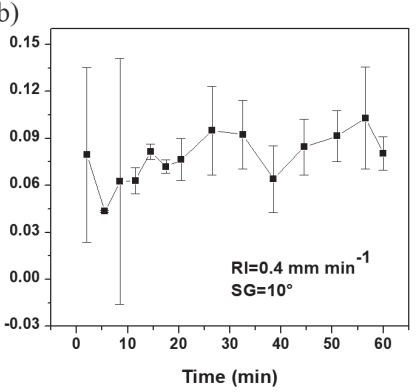

f)

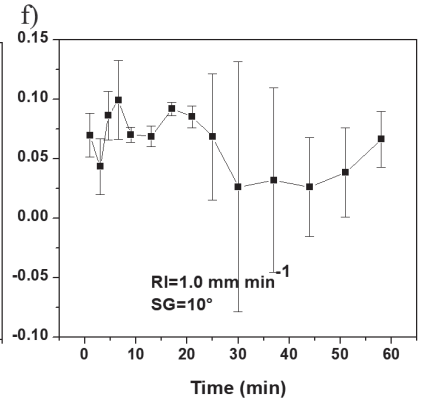

j)

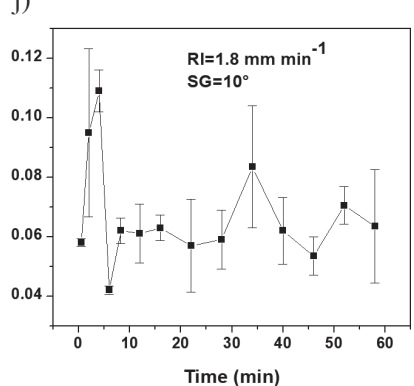

c)
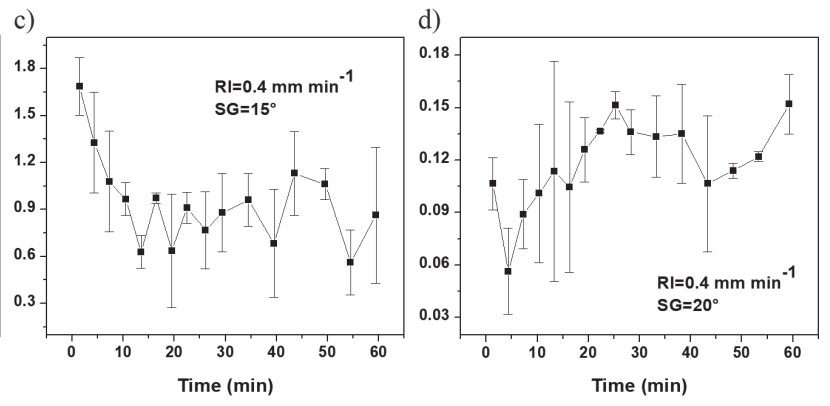

h)

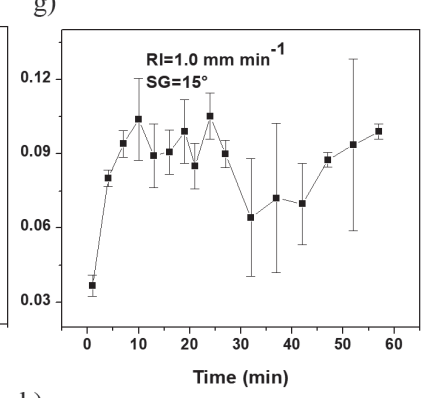

k)
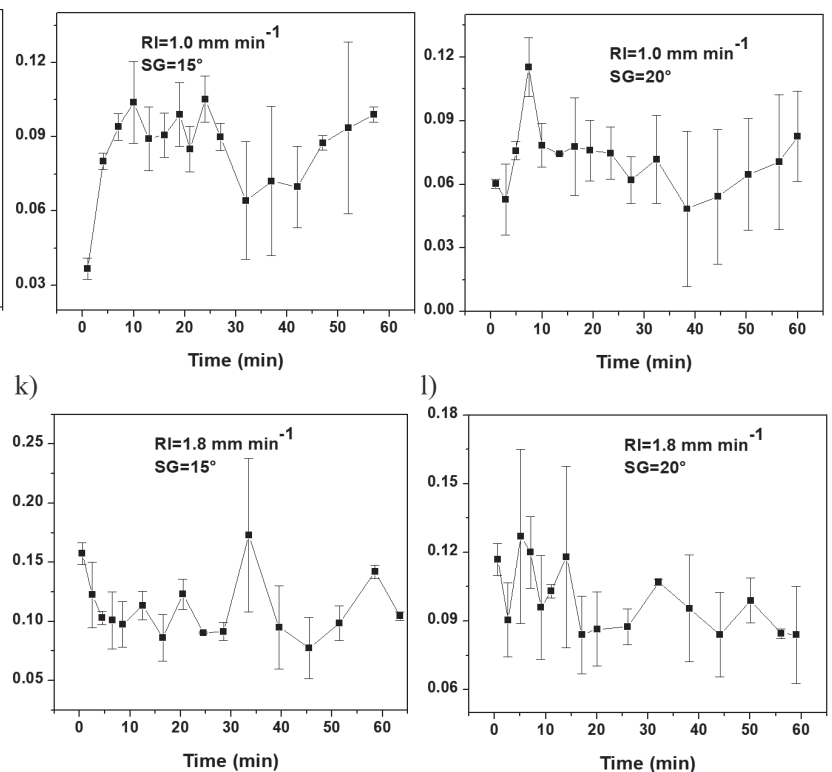
1)

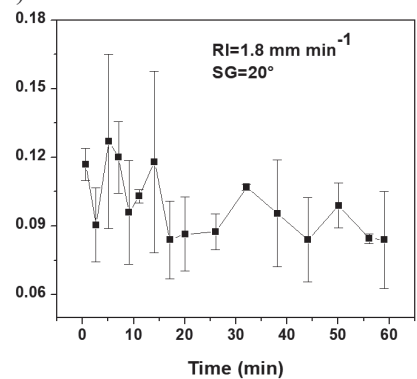

Fig. 2 Concentrations for NH4-N transfer to overland flow subjected to various RIs and SGs. 
a)

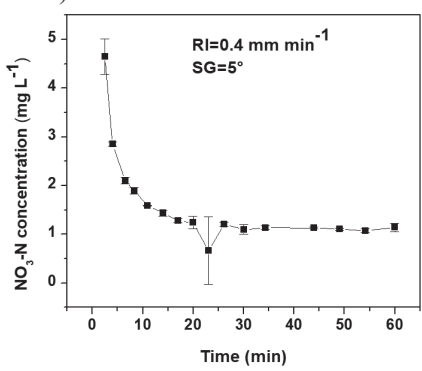

e)
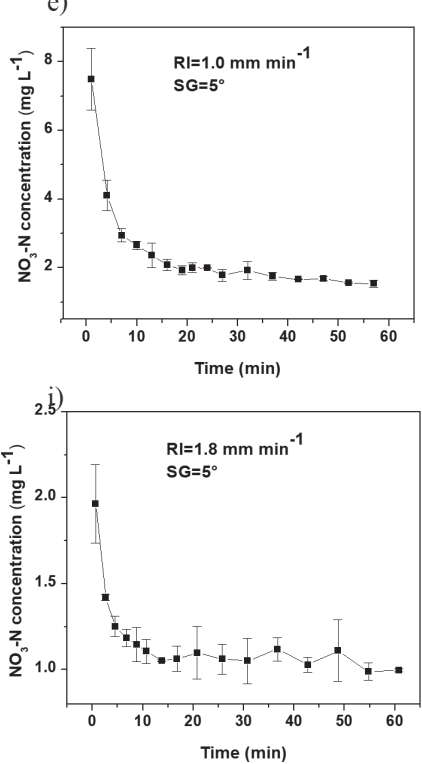

b)
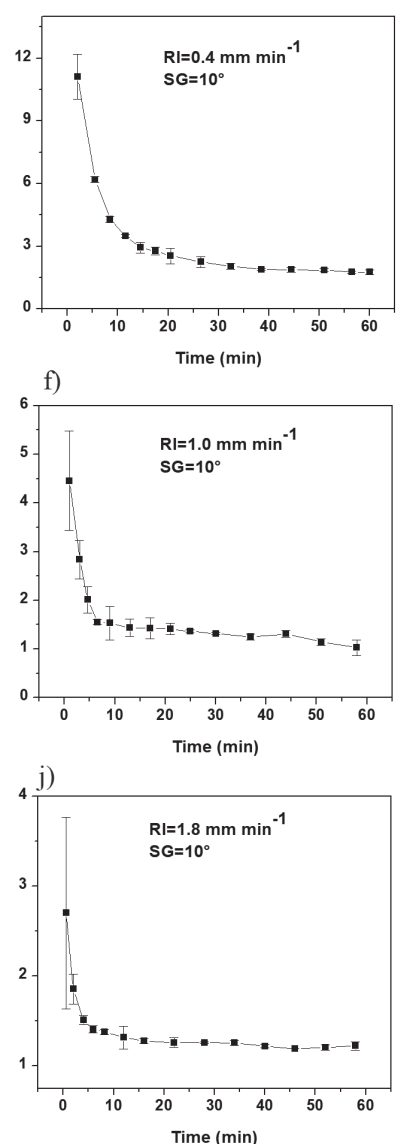

c)
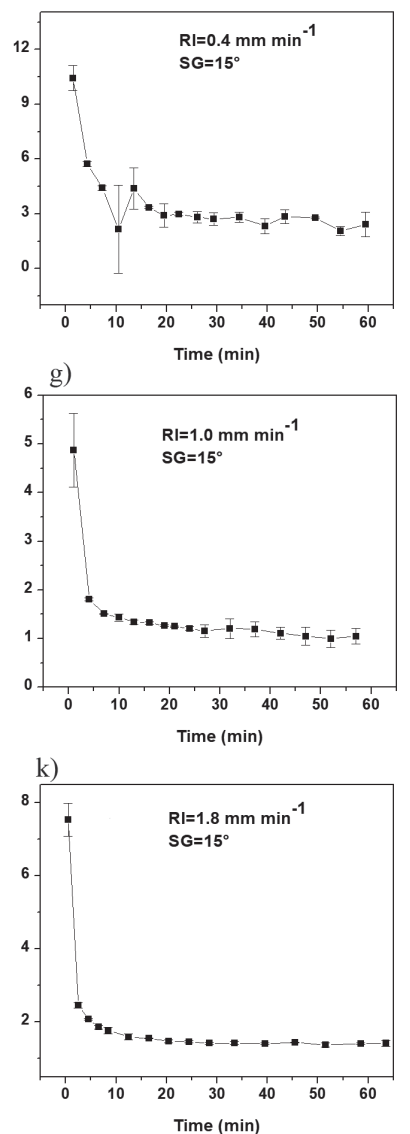

d)
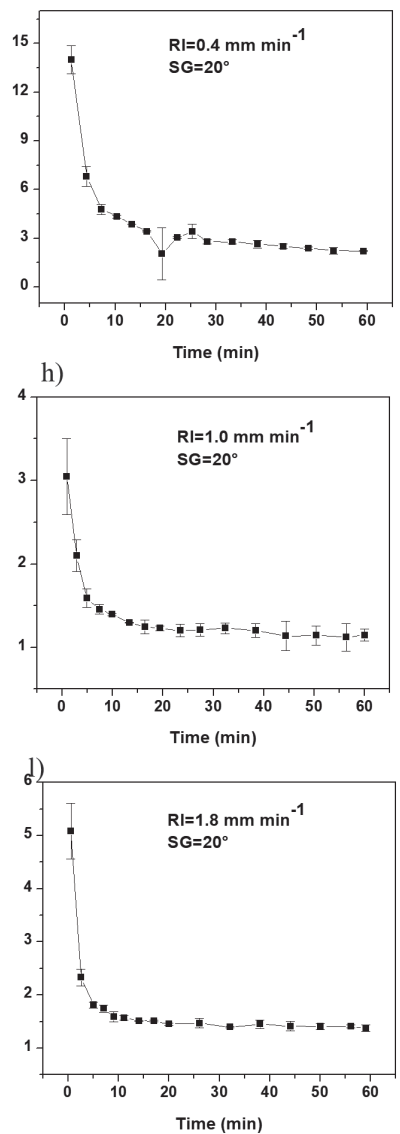

Fig. 3 Concentrations for NO3-N transfer to overland flow subjected to various RIs and SGs.

(Origin Lab Corp., USA), of which $r^{2}$, slopes and intercepts were presented to quantify the agreement between the measured and simulated data. IBM SPSS Statistics 20 (IBM Corp., USA) was applied to test the significance of regressions using ANOVA.

\section{Results and Discussion}

\section{N Transfer to Runoff in Response to Various RIs and SGs}

For $\mathrm{NH}_{4}-\mathrm{N}$ concentration in overland flow, it is observed that only Figs 2a) and c) showed noticeable decreases over time subjected to SG of $5^{\circ}$ and $15^{\circ}$ with low RI $\left(0.4 \pm 0.02 \mathrm{~mm} \mathrm{~min}^{-1}\right)$. For these two scenarios, the larger SG caused faster decreasing rate of concentration. The moderate $\left(1.0 \pm 0.04 \mathrm{~mm} \mathrm{~min}^{-1}\right)$ and high $\left(1.8 \pm 0.11 \mathrm{~mm} \mathrm{~min}^{-1}\right) \mathrm{RI}$ induced increasing concentration at the early stage of the rainfall. Overall, the error bars showed large variabilities of $\mathrm{NH}_{4}-\mathrm{N}$ concentration in runoff and the exponential decreasing trends for transport of $\mathrm{NH}_{4}-\mathrm{N}$ to runoff were not exactly presented in this study.

Fig. 4 shows that the exponential decrease of $\mathrm{TN}$ concentration only occurred subjected to the low RI $\left(0.4 \pm 0.02 \mathrm{~mm} \mathrm{~min}^{-1}\right)$. As a response to medium $\left(1.0 \pm 0.04 \mathrm{~mm} \mathrm{~min}^{-1}\right)$ and high $\left(1.8 \pm 0.11 \mathrm{~mm} \mathrm{~min}^{-1}\right)$ RIs, the deviations were relatively large and presented high variabilities, which was concordant with $\mathrm{NH}_{4}-\mathrm{N}$ transfers. This result was consistent with the findings of Armstrong et al. [5]. They also found TN dynamics, and transfer in runoff was highly variable and exhibited as much deviation between repeats by laboratory rainfall simulations.

Fig. 3 presents the $\mathrm{NO}_{3}-\mathrm{N}$ concentration in runoff subjected to 12 treatments. The error bar of each data point was relatively minor in comparison with $\mathrm{NH}_{4}-\mathrm{N}$ and $\mathrm{TN}$ concentrations. It is apparent that $\mathrm{NO}_{3}-\mathrm{N}$ concentrations declined linearly at the initial stage of the rainfall and then tended to stabilize, which was extremely similar to the results of previous works mentioned above. Moreover, high RI was much more likely to intensify the decrease rates of $\mathrm{NO}_{3}-\mathrm{N}$ concentration. It can be explained that heavy rainfall may fill the depressions in the microtopography in fast speed and form a surface seal to prevent soil chemical transport to runoff $[3,27]$. Also, this seal promoted runoff production, hence the decrease rates for chemical concentration correlated with the time to runoff $\left(\mathrm{t}_{\mathrm{p}}\right)$. We reckon that the higher RI formed a surface seal in a faster rate and led to fewer chemical transfers to runoff, hence the low concentrations for $\mathrm{N}$ subjected to high RI almost showed no significant exponential decreases. 
a)

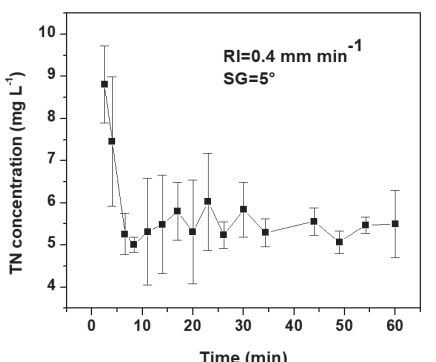

e)
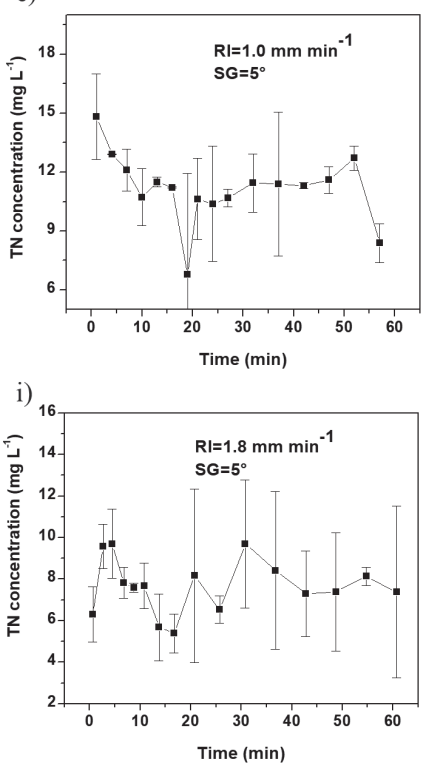

b)

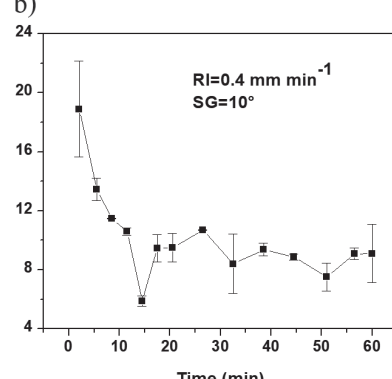

f)
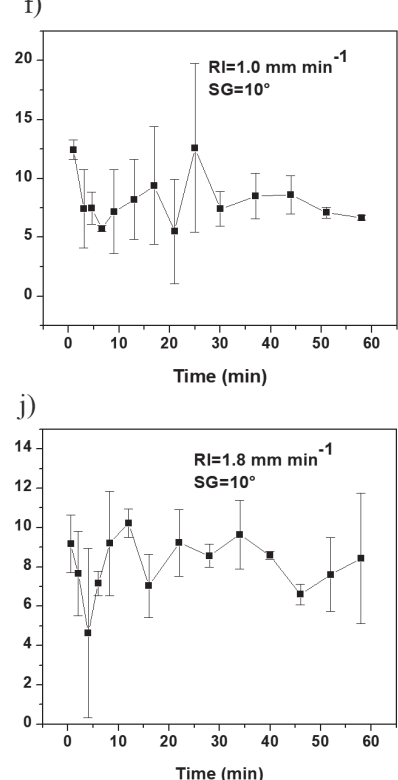

c)
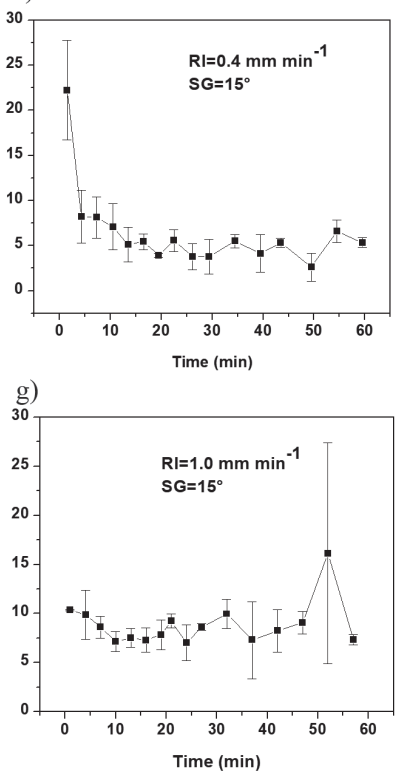

k)

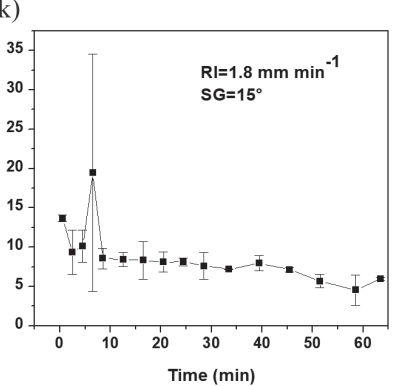

d)
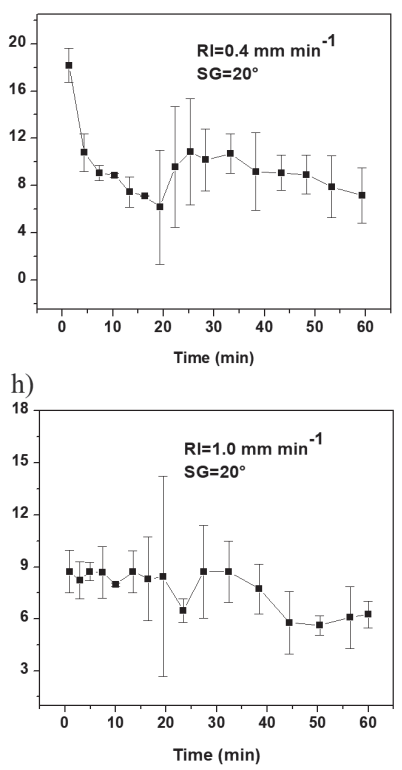

1)

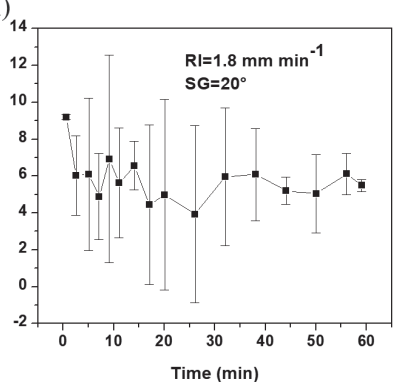

Fig. 4 Concentrations for TN transfer to overland flow subjected to various RIs and SGs.

Furthermore, the rapid formation of surface seal caused less mixing magnitude between the runoff and nitrogen in soil water.

Large numbers of prior works have described significant exponential decreasing trends of chemicals' (potassium, $\mathrm{Br}$, phosphorus, et al.) transport to runoff $[2,3,19]$. In our study, only $\mathrm{NO}_{3}-\mathrm{N}$ transfer displayed striking exponential decreases consistent with the effective mixing model proposed by Ahuja [19]. The facts that $\mathrm{NH}_{4}-\mathrm{N}$ and $\mathrm{TN}$ are absorbed by soil particles while $\mathrm{NO}_{3}-\mathrm{N}$ dissolves easily in soil water were responsible for less regular dynamics of $\mathrm{NH}_{4}-\mathrm{N}$ and $\mathrm{TN}$ than $\mathrm{NO}_{3}-\mathrm{N}$ concentration in runoff. We also speculated that the larger error bars for $\mathrm{NH}_{4}-\mathrm{N}$ and TN were derived from lability and digestion during determination, respectively. The mathematical model for the $\mathrm{NH}_{4}-\mathrm{N}$ and $\mathrm{TN}$ transport toward runoff requires further study.

Several studies have shown that time to runoff decreased significantly with increasing rainfall intensity $[28,29]$. In our study, the time to runoff is listed in Table 2 at about $2 \mathrm{~min}, 1 \mathrm{~min}$ and $0.5 \mathrm{~min}$ under RI of 0.4 $\mathrm{mm} \mathrm{min}{ }^{-1}, 1.0 \mathrm{~mm} \mathrm{~min}^{-1}$ and $1.8 \mathrm{~mm} \mathrm{~min}^{-1}$, respectively, which is consistent with the results of Bothma et al. [28]. Furthermore, the negative relationship between the slope gradient and $t_{p}$ indicated that steep slope intensified the decrease rate as shown in Fig. 3. In addition, the differences in the $\mathrm{N}$ behavior could be attributed to processes in relation to surface connectivity and flow networks [5].

\section{Model Performance}

\section{Effects of RI and SG on Effective Mixing Depth}

The effective mixing model is widely applied to simulate chemical transfer to runoff with the assumption that rainfall and runoff mixed completely with soil solution within an effective depth of soil, $h_{m}$. The original model was refined by replacing the timeaveraged $h_{m}$ as a time-increasing $h_{m}$. Both models were used to predict $\mathrm{N}$ concentrations in runoff and evaluated performance with experimental data. Parameters in the model were measured directly. The saturated water content, $\theta_{\mathrm{s}}$, was $0.495 \mathrm{~cm}^{3} \mathrm{~cm}^{-3}$ measured by normal method. Soil density, $\rho_{s}$, was $1.35 \mathrm{~g} \mathrm{~cm}^{-3}$ determined using the data when soils filled the tank. The runoff time for various treatments, $t_{p}$, were measured by stopwatch and listed in Table 2. Rainfall intensities, R, were $0.4,1.0$ and $1.8 \mathrm{~mm} \mathrm{~min}^{-1}$. The soil adsorption rates obtained by linear isothermal adsorption method [24], 
Table 2. Parameters in the two mathematical models.

\begin{tabular}{|c|c|c|c|c|c|c|}
\hline \multirow{2}{*}{$\begin{array}{c}\text { Scenario } \\
\mathrm{SG} / \mathrm{RI}^{\mathrm{a}}\left(\% / \mathrm{mm} \mathrm{min}^{-1}\right) \\
\end{array}$} & \multicolumn{3}{|c|}{$\mathrm{C}_{0}\left(\mathrm{mg} \mathrm{L}^{-1}\right)$} & \multirow{2}{*}{$\begin{array}{c}\mathrm{t}_{\mathrm{p}} \\
(\min ) \\
\end{array}$} & \multirow{2}{*}{$h_{m}(\mathrm{~cm})$} & \multirow{2}{*}{$\mathrm{h}_{0}(\mathrm{~cm})$} \\
\hline & $\mathrm{NH}_{4}-\mathrm{N}$ & $\mathrm{NO}_{3}-\mathrm{N}$ & $\mathrm{TN}$ & & & \\
\hline $5 / 0.4$ & 0.258 & 4.648 & 8.815 & 2.5 & 0.43 & 0.062 \\
\hline $10 / 0.4$ & 0.180 & 11.356 & 18.900 & 2.0 & 0.38 & 0.055 \\
\hline $15 / 0.4$ & 1.688 & 10.426 & 22.238 & 1.5 & 0.36 & 0.023 \\
\hline $20 / 0.4$ & 0.227 & 14.005 & 18.188 & 1.3 & 0.35 & 0.017 \\
\hline $5 / 1.0$ & 0.150 & 7.489 & 14.813 & 1.0 & 1.43 & 0.626 \\
\hline $10 / 1.0$ & 0.100 & 4.460 & 12.450 & 1.0 & 1.28 & 0.334 \\
\hline $15 / 1.0$ & 0.160 & 4.875 & 10.375 & 1.0 & 1.19 & 0.328 \\
\hline $20 / 1.0$ & 0.110 & 3.049 & 8.738 & 0.91 & 1.12 & 0.652 \\
\hline $5 / 1.8$ & 0.119 & 1.965 & 10.700 & 0.67 & 5.08 & 2.883 \\
\hline $10 / 1.8$ & 0.085 & 2.700 & 12.238 & 0.58 & 4.05 & 1.532 \\
\hline $15 / 1.8$ & 0.193 & 7.541 & 13.700 & 0.50 & 2.03 & 1.093 \\
\hline $20 / 1.8$ & 0.188 & 5.085 & 9.200 & 0.58 & 1.82 & 0.843 \\
\hline
\end{tabular}

${ }^{a}$ Totally twelve scenarios comprised four SGs $\left(5^{\circ}, 10^{\circ}, 15^{\circ}\right.$ and $\left.20^{\circ}\right)$ and three RIs $\left(0.4,1.0\right.$ and $\left.1.8 \mathrm{~mm} \mathrm{~min}^{-1}\right)$. The subsequent Tables followed this definition.

were 2.34, 0.83 and $2.06 \mathrm{~cm}^{3} \mathrm{~g}^{-1}$ for $\mathrm{NH}_{4}-\mathrm{N}, \mathrm{NO}_{3}-\mathrm{N}$ and TN respectively. For the refined time-increasing $h_{m}$, the basic mixing depth parameter, $\mathrm{h}_{\mathrm{n}}$ was determined using $1 \mathrm{~cm}$ as the simplicity of the effective mixing model and we achieved optimal fitted results at this value while the initial mixing depth parameter, $\mathrm{h}_{0}$, was obtained from curve fitting as well as time-averaged $\mathrm{h}_{\mathrm{m}}$ in the original model.

The effective mixing depth deduced from fitting results, $h_{m}$ and $h_{0}$, was various in response to different RIs and SGs (Table 2). Fig. 5 displays positive correlations between $h_{m}$ and RI, which is especially significant for gentle slope. In comparison, striking negative correlations were presented between $h_{m}$ and SG - especially for high RI. Prior works have indicated that rainfall intensity and slope gradient both had a positive relationship with $\mathrm{h}_{\mathrm{m}}[3,16,22]$. In our study, the increasing SGs attenuated positive relationships between RI and $h_{m}$ (Fig. 5a). The large RI with high rainfall kinetic energy enhanced the interaction of rainfall, runoff and soil solute [19]. Although the effective mixing depth was enhanced by higher RI, the mixing magnitude was still weakened by the formation of surface seal in a faster speed as discussed in section 3.1. Ahuja [19] also pointed out that higher SGs intensified the effects of kinetic energy. Yang et al. [3] concluded an exponential increase between SGs and $h_{m}$. However, the SGs correlated with $h_{m}$ negatively, especially under high RI (Fig. 5b) in this study. Mohamed and Kohl [27] concluded that a thinner and less compacted seal formed at the soil surface with a low kinetic energy rainfall. Hence, the seal at the soil surface could be compacted by the intensified effects of kinetic energy with increasing SGs [19]. This seal may prevent the interaction of rainfall, runoff and soil solute to some degree. Thus it can be seen that a seal
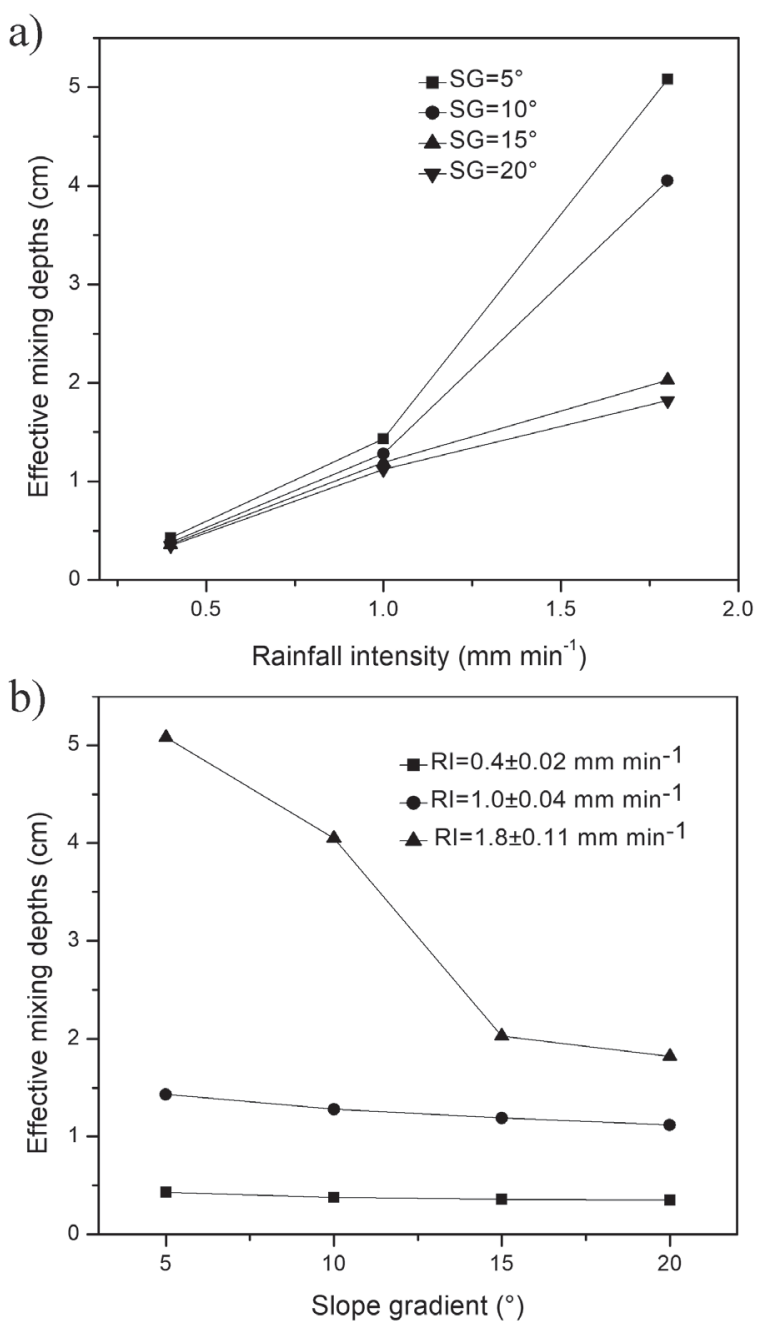

Fig. 5 Relationships between the effective mixing depth and RIs a) and SGs b). 


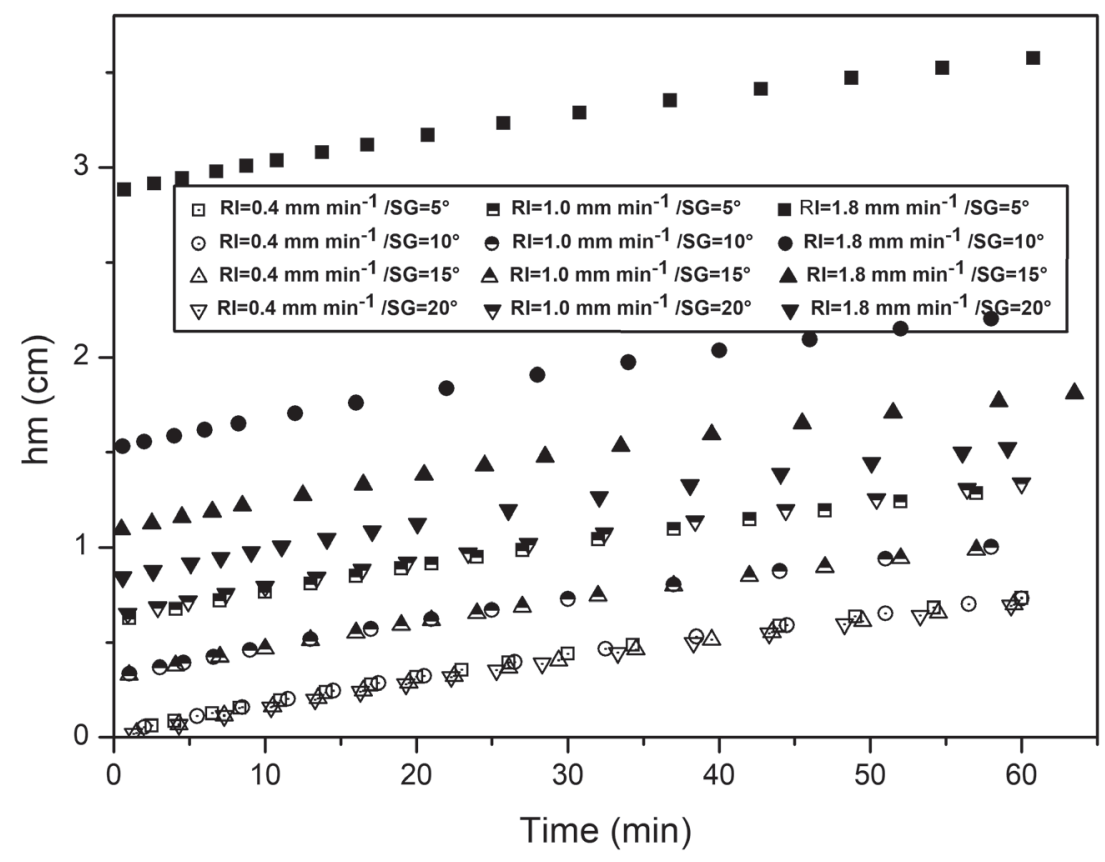

Fig. 6 The variation of effective mixing depth in refined model for all treatments.

at soil surface could be an explanation for negative relationships between $\mathrm{h}_{\mathrm{m}}$ and SGs. Additionally, soil particles expressed resistance to the rainfall detachment [30]. The tested soil in the study of Yang et al. [3] was collected from the Loess Plateau, which was more loose with more slight soil particles than our tested loam [31]. Consequently, less resistance to rainfall detachment of their soils may lead to increasing mixing depth with increasing SGs. In contrast, the loam in our study possessed good resistance to rainfall detachment and the increasing SGs may enhance this resistance, causing a decrease in mixing depth.

For $h_{m}$ in refined model, the $h_{0}$ mostly showed the same regularity as the $h_{m}$ in the effective mixing model as a response to various RIs and SGs (Table 2). The $\mathrm{h}_{\mathrm{m}}$ increments with time are presented in Fig. 6, and the increasing trends for all treatments showed uniformities with faster growing rates at the early stages than later stages. We consider that effective mixing depth existed when runoff happened. Hence, exactly as in Eq. (4) displays, the time-increasing $h_{m}$ is determined by the $h_{0}$ and $h_{n}$, and the $h_{n}$ was deduced and simplified by using $1 \mathrm{~cm}$ as a constant. Therefore, the variation of $h_{m}$ under different treatments was mainly determined directly by the $h_{0}$. Yang et al. $[20,32]$ also applied exponential time-increasing $h_{m}$ in studies of chemical transfer to runoff, and the $h_{m}$ increased from $0 \mathrm{~cm}$ based on the exponential dependences. Given that the effective mixing depth is a critical factor for chemical transfer from soil to overland flow and the initial concentration of chemical in runoff was maximum, we reckoned that a certain initial mixing depth was required for the chemical transfer to run off.

\section{Model Evaluation}

In order to evaluate the applicability of the mathematical models and compare the simulated results between the effective mixing model and our refined model, the $\mathrm{N}$ concentrations in runoff observed experimentally and calculated with these two mathematical models are presented in Figs 7 and 8 . Also, the parameters of linear regressions and RMSE for $\mathrm{NH}_{4}-\mathrm{N}, \mathrm{NO}_{3}-\mathrm{N}$ and $\mathrm{TN}$ are listed respectively in Tables 3, 4 and 5. As shown in Figs. 7 and 8, the $\mathrm{C}_{0}$ values (Table 2) were obtained with the corresponding initial maximum values for the normal decreasing $\mathrm{N}$ concentrations. Fig. 7 shows that the simulated curves could not fit well with experimental data of $\mathrm{N}$ concentration both at the decreasing stage and the stable stage. However, the simulated curves of refined model in Fig. 8 show better goodness of fit - especially for low RI (Fig. 8a, d and g). Specifically, both the predictions of decreasing and stable trends were improved by refined model - especially for the $\mathrm{NO}_{3}-\mathrm{N}$.

Fig. 9 shows the linear regressions between measured experimentally data versus simulated data of effective mixing depth model. It can be observed that the $r^{2}$ for $\mathrm{NH}_{4}-\mathrm{N}, \mathrm{NO}_{3}-\mathrm{N}$, and TN were $0.2538(p<0.001), 0.6960$ $(p<0.001)$, and $0.2240 \quad(p<0.001)$ respectively. The $p$-Values showed significance for linear regressions of $\mathrm{N}$ concentrations using all data. However, $p$-Values of each scenario were larger with less significance, especially for $\mathrm{NH}_{4}-\mathrm{N}$ and $\mathrm{TN}$, due to fewer data points in one scenario. The $r^{2}$ for $\mathrm{NH}_{4}-\mathrm{N}$ and $\mathrm{TN}$ were relatively low, but the slopes were 0.7916 and 0.6658 close to 1 , respectively, and $r^{2}$ was only one fraction of what it was for the regression. As indicated in Tables 3, 4 and 
Table 3 Parameters from linear regressions and RMSE of simulated versus measured concentrations in runoff for NH4-N under various scenarios.

\begin{tabular}{|c|c|c|c|c|c|c|c|c|c|}
\hline \multirow[b]{2}{*}{ Variable } & \multirow[b]{2}{*}{ Scenario } & \multicolumn{3}{|c|}{ Model } & \multirow{2}{*}{$\begin{array}{l}\text { RMSE } \\
\left(\mathrm{mg} \mathrm{L}^{-1}\right)\end{array}$} & \multicolumn{3}{|c|}{ Refined model } & \multirow{2}{*}{$\begin{array}{l}\text { RMSE } \\
\left(\mathrm{mg} \mathrm{L}^{-1}\right)\end{array}$} \\
\hline & & $r^{2}(p$-Value $)$ & Slope & Intercept & & $\begin{array}{c}r^{2} \\
(p-\text {-Value })\end{array}$ & Slope & Intercept & \\
\hline \multirow{13}{*}{$\mathrm{NH}_{4}-\mathrm{N}$} & $5 / 0.4$ & $0.8836(<0.001)$ & 1.0340 & 0.0019 & 0.0227 & $0.7702(<0.001)$ & 0.5920 & 0.0607 & 0.0299 \\
\hline & $10 / 0.4$ & $0.3841(0.018)$ & -1.9042 & 0.2460 & 0.0610 & $0.1654(0.149)$ & -0.5880 & 0.1294 & 0.0321 \\
\hline & $15 / 0.4$ & $0.3096(0.025)$ & 0.8661 & 0.0694 & 0.3633 & $0.5873(0.001)$ & 0.6474 & 0.2661 & 0.2040 \\
\hline & $20 / 0.4$ & $0.4272(0.006)$ & -2.2901 & 0.4398 & 0.0751 & $0.2086(0.125)$ & -0.6089 & 0.1900 & 0.0459 \\
\hline & $5 / 1.0$ & $0.1308(0.169)$ & 0.7269 & 0.0347 & 0.0301 & $0.0577(0.370)$ & 0.4851 & 0.0420 & 0.0303 \\
\hline & $10 / 1.0$ & $0.2831(0.050)$ & 0.5086 & 0.0353 & 0.0231 & $0.1800(0.131)$ & 0.5568 & 0.0309 & 0.0305 \\
\hline & $15 / 1.0$ & $0.0472(0.419)$ & -0.4498 & 0.1359 & 0.0139 & $0.1613(0.123)$ & -0.8181 & 0.1417 & 0.0459 \\
\hline & $20 / 1.0$ & $0.0394(0.461)$ & 0.3604 & 0.0410 & 0.0288 & $0.0228(0.577)$ & 0.3059 & 0.0601 & 0.0336 \\
\hline & $5 / 1.8$ & $0.2110(0.073)$ & -0.4303 & 0.1332 & 0.0309 & $0.2204(0.067)$ & -0.6001 & 0.1694 & 0.0465 \\
\hline & $10 / 1.8$ & $0.0438(0.473)$ & 0.1777 & 0.0541 & 0.0198 & $0.0587(0.404)$ & 0.2966 & 0.0329 & 0.0274 \\
\hline & $15 / 1.8$ & $0.0178(0.622)$ & 0.2566 & 0.0875 & 0.0529 & $0.0330(0.501)$ & 0.3549 & 0.0605 & 0.0533 \\
\hline & $20 / 1.8$ & $0.3459(0.017)$ & 2.0103 & -0.0885 & 0.0435 & $0.3449(0.017)$ & 2.0926 & -0.1146 & 0.0445 \\
\hline & All & $0.2538(<0.001)$ & 0.7916 & 0.0312 & 0.0501 & $0.2660(<0.001)$ & 0.6319 & 0.0344 & 0.0394 \\
\hline
\end{tabular}

5 , the parameters of linear regressions in response to low RI were significantly superior to that of moderate and high RIs. In comparison, the $r^{2}$ and slope of refined model were, respectively, 0.266 and 0.6319 for $\mathrm{NH}_{4}-\mathrm{N}$; 0.8276 and 0.9996 for $\mathrm{NO}_{3}-\mathrm{N}$; and 0.241 and 0.5993 for TN (Fig. 10), and RMSE between the refined model and the original model were $0.0394 \mathrm{mg} \mathrm{L}^{-1}$ and
$0.0501 \mathrm{mg} \mathrm{L}^{-1}$ for $\mathrm{NH}_{4}-\mathrm{N}, 0.8367 \mathrm{mg} \mathrm{L}^{-1}$ and $1.3922 \mathrm{mg}$ $\mathrm{L}^{-1}$ for $\mathrm{NO}_{3}-\mathrm{N}$, and $3.4455 \mathrm{mg} \mathrm{L}^{-1}$ and $3.6525 \mathrm{mg} \mathrm{L}^{-1}$ for $\mathrm{TN}$, respectively. The fitting results of $\mathrm{NO}_{3}-\mathrm{N}$ transport were significantly improved, although no improvements for $\mathrm{NH}_{4}-\mathrm{N}$ and $\mathrm{TN}$ transfer to runoff. It can be deduced that the data obtained experimentally for $\mathrm{NH}_{4}-\mathrm{N}$ and $\mathrm{TN}$ with large deviation and no significant

Table 4 Parameters from linear regressions and RMSE of simulated versus measured concentrations in runoff for $\mathrm{NO}_{3}-\mathrm{N}$ under various scenarios.

\begin{tabular}{|c|c|c|c|c|c|c|c|c|c|}
\hline \multirow{2}{*}{ Variable } & \multirow{2}{*}{ Scenario } & \multicolumn{3}{|c|}{ Model } & \multirow{2}{*}{$\begin{array}{l}\text { RMSE } \\
\left(\mathrm{mg} \mathrm{L}^{-1}\right)\end{array}$} & \multicolumn{3}{|c|}{ Refined model } & \multirow{2}{*}{$\begin{array}{l}\text { RMSE } \\
\left(\mathrm{mg} \mathrm{L}^{-1}\right)\end{array}$} \\
\hline & & $r^{2}(p$-Value $)$ & Slope & Intercept & & $r^{2}(p$-Value $)$ & Slope & Intercept & \\
\hline \multirow{13}{*}{$\mathrm{NO}_{3}-\mathrm{N}$} & $5 / 0.4$ & $0.6665(<0.001)$ & 1.2570 & -0.1137 & 0.9128 & $0.9555(<0.001)$ & 1.0544 & -0.1803 & 0.2372 \\
\hline & $10 / 0.4$ & $0.8047(<0.001)$ & 1.2233 & -0.3678 & 1.6267 & $0.9840(<0.001)$ & 0.9590 & 0.0711 & 0.3243 \\
\hline & $15 / 0.4$ & $0.6863(<0.001)$ & 1.2744 & -1.2937 & 1.8360 & $0.9209(<0.001)$ & 1.0108 & -0.9820 & 1.1143 \\
\hline & $20 / 0.4$ & $0.7388(<0.001)$ & 1.2330 & -0.5870 & 2.2176 & $0.9549(<0.001)$ & 0.9678 & -0.4104 & 0.8102 \\
\hline & $5 / 1.0$ & $0.6600(<0.001)$ & 1.1544 & 0.4292 & 1.4616 & $0.8427(<0.001)$ & 1.2317 & -0.6140 & 0.8393 \\
\hline & $10 / 1.0$ & $0.5824(0.001)$ & 1.2083 & 0.0284 & 0.9905 & $0.8624(<0.001)$ & 1.3532 & -1.0562 & 0.7210 \\
\hline & $15 / 1.0$ & $0.5157(0.002)$ & 1.1042 & 0.2495 & 1.0455 & $0.8207(<0.001)$ & 1.2424 & -0.7681 & 0.6965 \\
\hline & $20 / 1.0$ & $0.7425(<0.001)$ & 2.9673 & -2.8053 & 0.6622 & $0.7641(<0.001)$ & 1.5771 & -1.1243 & 0.5983 \\
\hline & $5 / 1.8$ & $0.4211(0.007)$ & 1.3056 & -0.2499 & 0.3753 & $0.4600(0.002)$ & 1.4249 & -0.4706 & 0.3700 \\
\hline & $10 / 1.8$ & $0.4608(0.008)$ & 1.2758 & -0.2032 & 0.5805 & $0.6202(0.001)$ & 1.7340 & -1.3694 & 0.6794 \\
\hline & $15 / 1.8$ & $0.4087(0.008)$ & 1.0451 & 0.9072 & 2.0953 & $0.5375(0.001)$ & 1.1405 & 0.0646 & 1.6021 \\
\hline & $20 / 1.8$ & $0.4674(0.003)$ & 1.2276 & -0.2265 & 1.1883 & $0.6635(<0.001)$ & 1.3539 & -1.0300 & 0.9909 \\
\hline & All & $0.6960(<0.001)$ & 1.1617 & -0.0438 & 1.3922 & $0.8267(<0.001)$ & 0.9996 & -0.2675 & 0.8367 \\
\hline
\end{tabular}


Table 5 Parameters from linear regressions and RMSE of simulated versus measured concentrations in runoff for TN under various scenarios

\begin{tabular}{|c|c|c|c|c|c|c|c|c|c|}
\hline \multirow{2}{*}{ Variable } & \multirow{2}{*}{ Scenario } & \multicolumn{3}{|c|}{ Model } & \multirow{2}{*}{$\begin{array}{c}\text { RMSE } \\
\left(\mathrm{mg} \mathrm{L}^{-1}\right)\end{array}$} & \multicolumn{3}{|c|}{ Refined model } & \multirow{2}{*}{$\begin{array}{l}\text { RMSE } \\
\left(\mathrm{mg} \mathrm{L}^{-1}\right)\end{array}$} \\
\hline & & $r^{2}(p$-Value $)$ & Slope & Intercept & & $r^{2}(p$-Value $)$ & Slope & Intercept & \\
\hline \multirow{13}{*}{$\mathrm{TN}$} & $5 / 0.4$ & $0.2572(0.045)$ & 1.1938 & -1.7132 & 2.0437 & $0.6454(<0.001)$ & 1.1713 & -1.9162 & 1.2669 \\
\hline & $10 / 0.4$ & $0.4443(0.009)$ & 1.1481 & -1.9465 & 3.8594 & $0.7713(<0.001)$ & 0.8775 & 0.9787 & 1.4871 \\
\hline & $15 / 0.4$ & $0.4150(0.007)$ & 0.8682 & 5.4528 & 6.4577 & $0.8870(<0.001)$ & 0.7083 & 6.2189 & 4.6595 \\
\hline & $20 / 0.4$ & $0.2295(0.060)$ & 0.8692 & 0.7084 & 4.2423 & $0.6924(<0.001)$ & 0.8388 & 0.7388 & 1.3910 \\
\hline & $5 / 1.0$ & $0.1326(0.166)$ & 0.6541 & 2.0229 & 3.4952 & $0.2152(0.070)$ & 0.8313 & -1.4065 & 4.3054 \\
\hline & $10 / 1.0$ & $0.0194(0.635)$ & 0.2056 & 6.3573 & 3.3990 & $0.0418(0.483)$ & 0.3132 & 3.3410 & 4.0636 \\
\hline & $15 / 1.0$ & $0.0263(0.549)$ & -0.1793 & 7.1673 & 4.4720 & $0.0001(0.967)$ & -0.0120 & 4.4311 & 5.5341 \\
\hline & $20 / 1.0$ & $0.5467(0.001)$ & 1.4325 & -5.9926 & 3.1097 & $0.4782(0.003)$ & 1.1839 & -4.2713 & 3.2081 \\
\hline & $5 / 1.8$ & $0.0004(0.942)$ & 0.0257 & 8.2754 & 2.1946 & $0.0008(0.920)$ & 0.0381 & 7.8738 & 2.1880 \\
\hline & $10 / 1.8$ & $0.0084(0.755)$ & -0.1449 & 10.433 & 2.9653 & $0.0177(0.650)$ & -0.2965 & 9.6551 & 3.7114 \\
\hline & $15 / 1.8$ & $0.5012(0.002)$ & 0.7644 & 1.1204 & 2.8682 & $0.5014(0.002)$ & 0.7734 & -0.1044 & 3.4372 \\
\hline & $20 / 1.8$ & $0.1877(0.094)$ & 0.9290 & -0.2052 & 2.3329 & $0.2811(0.035)$ & 1.1371 & -2.4472 & 2.6903 \\
\hline & All & $0.2240(<0.001)$ & 0.6658 & 2.3701 & 3.6525 & $0.2410(<0.001)$ & 0.5993 & 2.0375 & 3.4456 \\
\hline
\end{tabular}
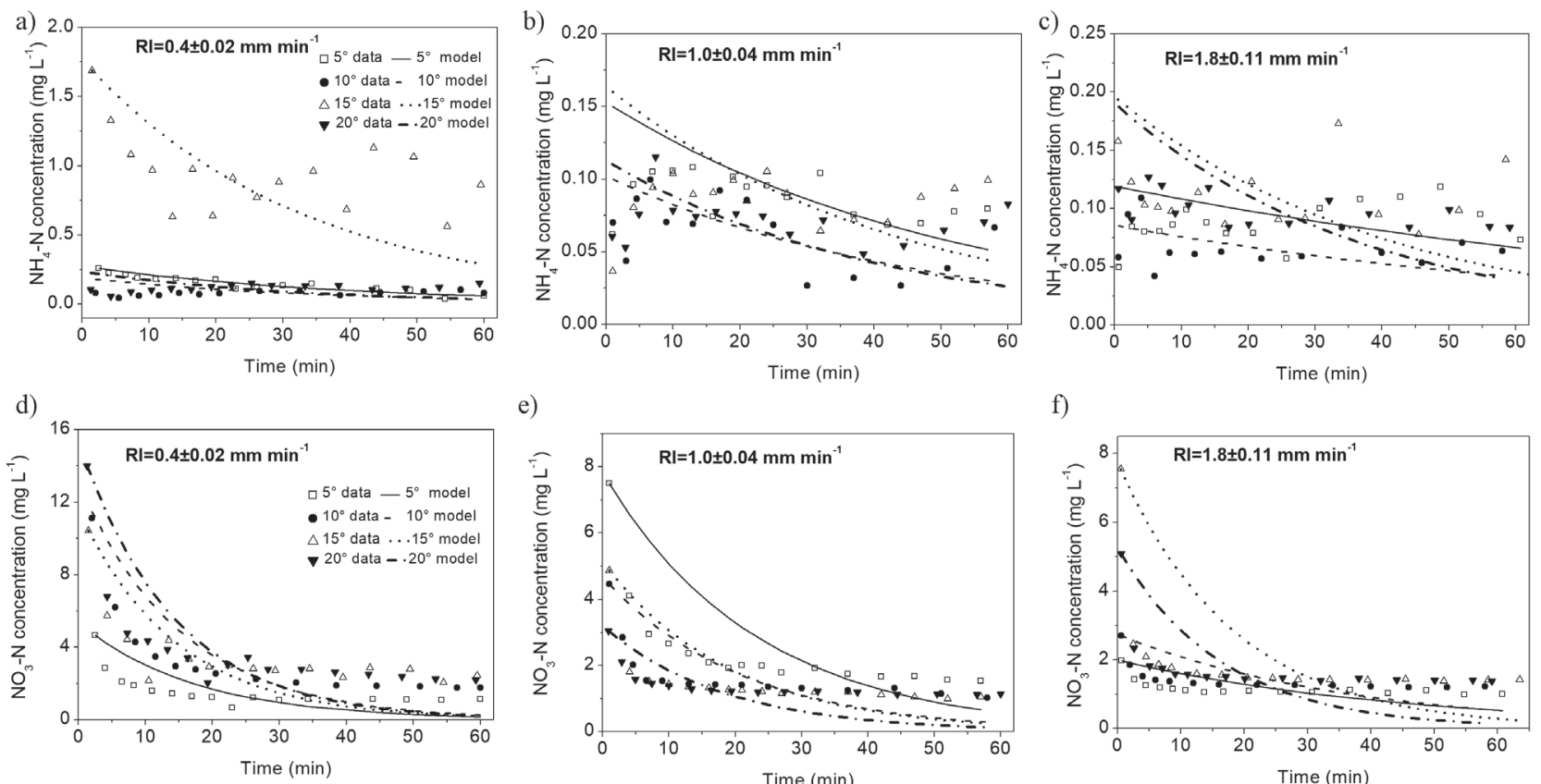

e)

f)
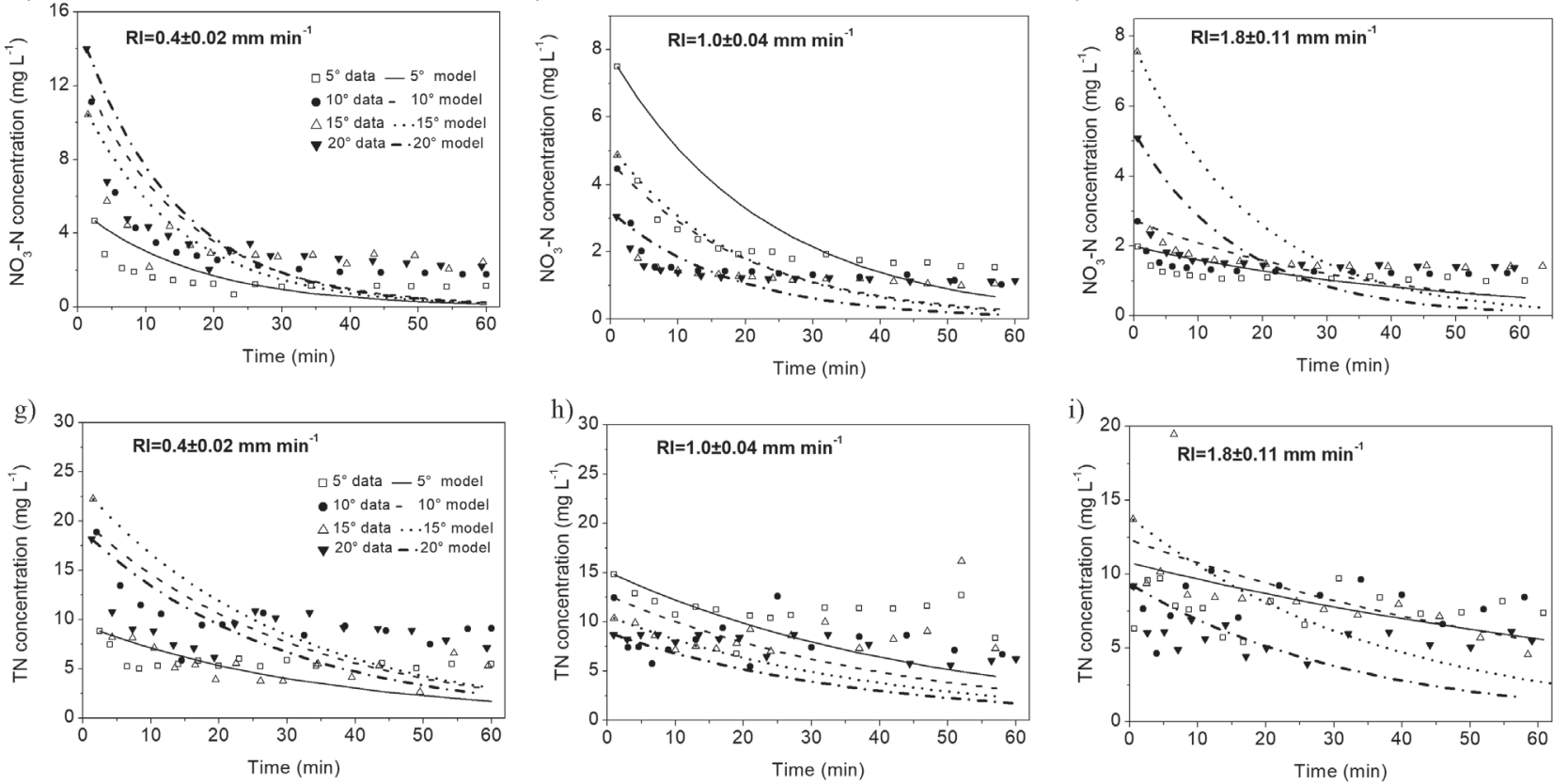

Fig. 7 Fitted results between experimentally observed data and simulated concentrations of $\left.\mathrm{NH}_{4}-\mathrm{N} \mathrm{a-c}\right), \mathrm{NO}_{3}-\mathrm{N} \mathrm{d}-\mathrm{f}$ ) and $\mathrm{TN}$ g-j) by the effective mixing model. 

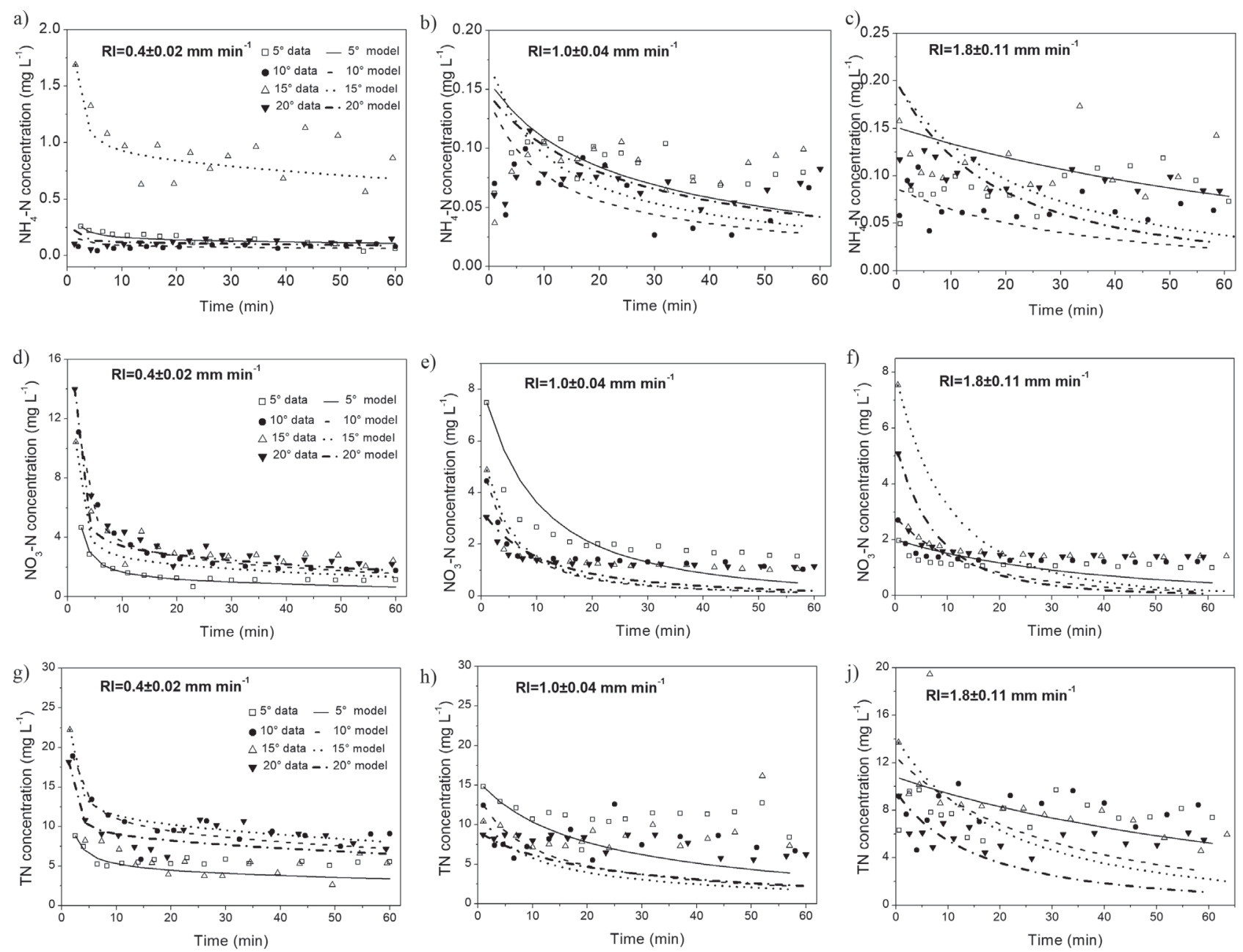

Fig. 8 Fitted results between experimentally observed data and simulated concentrations of $\left.\mathrm{NH}_{4}-\mathrm{N} \mathrm{a}-\mathrm{c}\right), \mathrm{NO}_{3}-\mathrm{N}$ d-f) and $\mathrm{TN}$ g-j) by the refined effective mixing model.

decreases caused the badness of fits. Noteworthy $r^{2}$ for $\mathrm{TN}$ in response to low RI via refined model were greater than the original model $[0.6369(p<0.001)$ versus $0.2572(p=0.045)$ for $\mathrm{SG}=5^{\circ} ; 0.7713(p<0.001)$ versus $0.4443(p=0.009)$ for $\mathrm{SG}=10^{\circ} ; 0.8870(p<0.001)$ versus $0.4150(p=0.007)$ for $\mathrm{SG}=15^{\circ}$; and 0.6924 $(p<0.001)$ versus $0.2295(p=0.060)$ for $\left.\mathrm{SG}=20^{\circ}\right]$, and the corresponding RMSE were smaller $\left(1.2669 \mathrm{mg} \mathrm{L}^{-1}\right.$ versus $2.0437 \mathrm{mg} \mathrm{L}^{-1}, \quad 1.4871 \mathrm{mg} \mathrm{L}^{-1}$ versus $3.8594 \mathrm{mg} \mathrm{L}^{-1}, 4.6595 \mathrm{mg} \mathrm{L}^{-1}$ versus $6.4577 \mathrm{mg} \mathrm{L}^{-1}$, and $1.3910 \mathrm{mg} \mathrm{L}^{-1}$ versus $4.2423 \mathrm{mg} \mathrm{L}^{-1}$, respectively for $\mathrm{SG}=5^{\circ}, 10^{\circ}, 15^{\circ}$ and $20^{\circ}$ ). It is therefore reckoned that the mathematical models were in agreement with prominent declines in experimentally observed data, especially under light rainfall. Furthermore, the refined model can be applied to chemical transport toward runoff with a higher accuracy because of significant improvements for $\mathrm{NO}_{3}-\mathrm{N}$ from the refined mathematical model (Table 4).

The simulated curves all present badness of fit subjected to high RI, which may derive from the small $\mathrm{C}_{0}$ values and personal irregular transfer with large variance. Yang et al. [3] compared the feasibility and applicability of effective mixing model calculated by Eq. (1) using potassium. The $\mathrm{C}_{0}$ in their study were calculated from the measured initial concentration [1] based on solute mass conservation equation in no accordance with experimental values. However, the experimental potassium transport to runoff presented significant exponential decrease and the model was in good agreement with measured data in the study of Yang et al. (2016a).

Several studies have reported high accuracy of model simulations for chemical transfer to runoff $[1,19,33]$. Tao et al. [26] revealed good fitness for a mathematical model of nutrient loss rate $\left(r^{2}\right.$ were 0.91 , 0.84 and 0.88 for $\mathrm{NH}_{4}-\mathrm{N}, \mathrm{NO}_{3}-\mathrm{N}$ and phosphorus, respectively) under various rainfall patterns. Yang et al. [3] reported $r^{2}$ and RMSE between experimental and the calculated potassium concentrations for the complete-mixing model, incomplete-mixing model and equivalent model were $0.951,0.938,0.972$ and 0.62 , $0.64,0.42 \mathrm{mg} \mathrm{L}^{-1}$, respectively. The model performance of their studies agreed well with the corresponding experimental results. In comparison, our simulation results with less accuracy for experimental data might 
be derived from the variation of experimental results and synchronous model fittings for $\mathrm{NH}_{4}-\mathrm{N}, \mathrm{NO}_{3}-\mathrm{N}$, and $\mathrm{TN}$ with the same effective mixing depth. Additionally, the observed dynamics of $\mathrm{NH}_{4}-\mathrm{N}$ and $\mathrm{TN}$ concentration in runoff showing less regular exponential declines
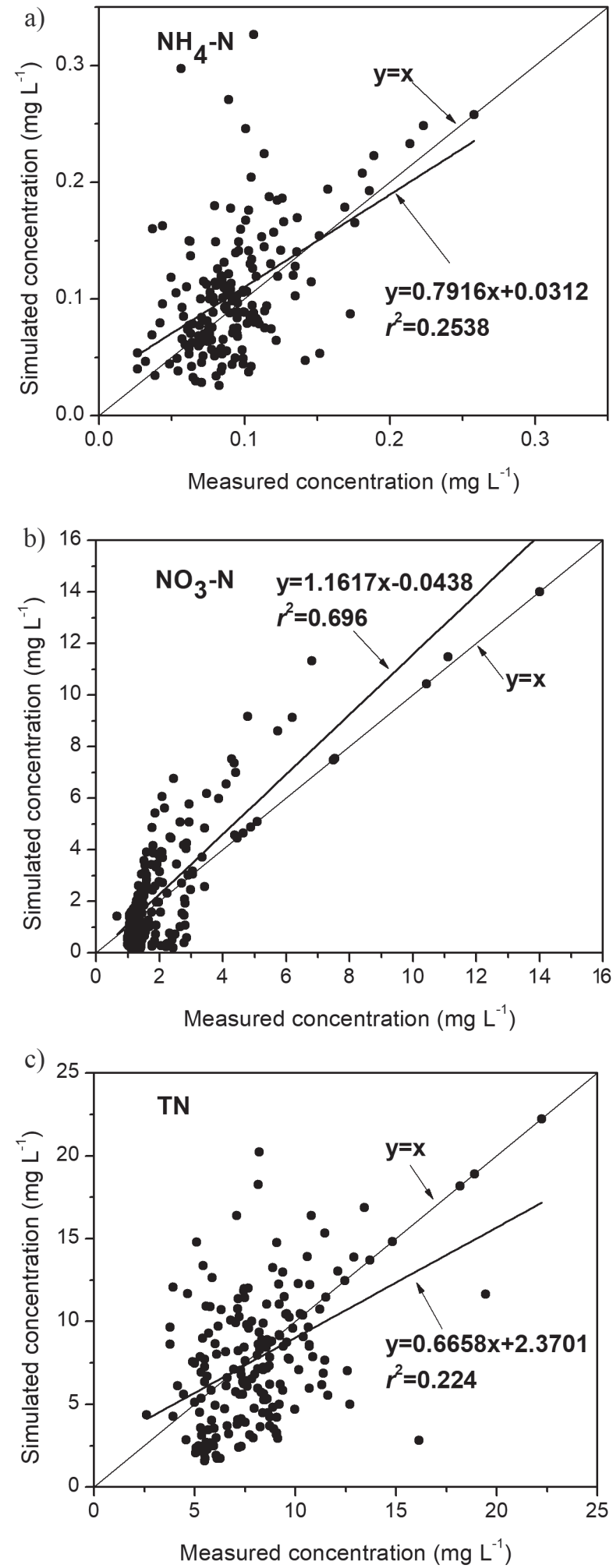

Fig. 9 Linear regressions of simulated and measured concentrations in runoff for $\mathrm{NH}_{4}-\mathrm{N} \mathrm{a}$ ), $\mathrm{NO}_{3}-\mathrm{N}$ b) and $\mathrm{TN}$ c) by the effective mixing model. were responsible for the badness of fit. Most worthy of mention is the fact that Yang et al. [32] reported $r^{2}$ for potassium, phosphorus and nitrate were $0.68,0.82$ and 0.57 by complete-mixing model, respectively, and 0.91 , 0.82 and 0.77 by incomplete-mixing model both based on the effective mixing model [16]. The prediction
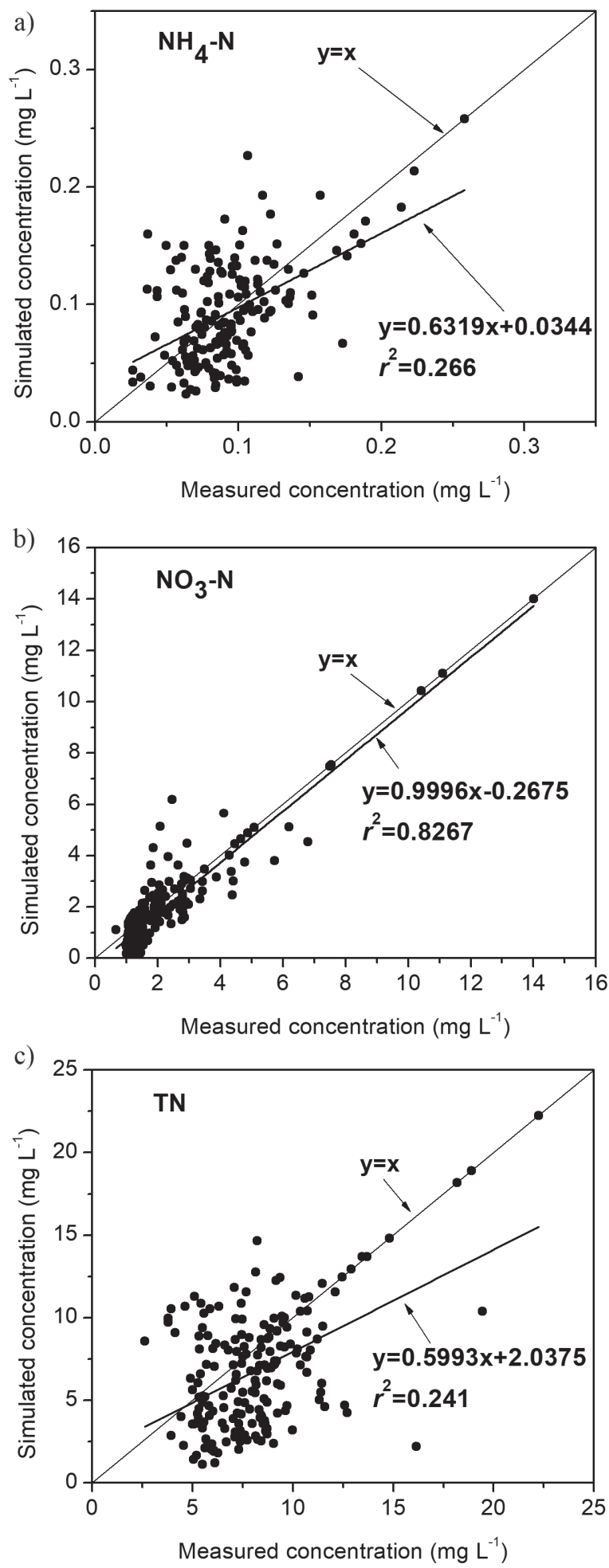

Fig. 10 Linear regressions of simulated and measured concentrations in runoff for $\mathrm{NH}_{4}-\mathrm{N}$ a), $\mathrm{NO}_{3}-\mathrm{N} \mathrm{b}$ ) and $\mathrm{TN}$ c) by the refined effective mixing model. 
results for potassium and phosphorus were both better than that for $\mathrm{NO}_{3}-\mathrm{N}$ in their studies [32]. Furthermore, the effective mixing model may indeed display less agreement when considering nitrogen transfers with erratic dynamics of concentration.

For $h_{m}$, Yang et al. [20] also showed that time-varied $\mathrm{h}_{\mathrm{m}}$ derived from the Kostiakov infiltration equation indicated a better fitness between experimental data and mathematical model based on solute mass conservation proposed by Ahuja et al. [16] as a response to water scouring than time-averaged $\mathrm{h}_{\mathrm{m}}$ in their previous study [3]. Similarly, the refined model in our study used a time-dependent $h_{m}$ and revealed better simulation results. In detail, the $h_{m}$ varied with time, presenting a higher increasing rate at the early stage of rainfall in this study, but a smaller and increasing growth rate with time was indicated in the study of Yang et al. [20]. Later, in further studies of Yang et al. [32], they proposed that $h_{m}$ was an exponential function as time considering mixing coefficient and inter-rill sediment delivery rate from soil under rainfall as a refinement in the effective mixing model [16]. They listed smaller $r^{2}$ for $\mathrm{NO}_{3}-\mathrm{N}$ than that in our study $(0.57$ versus 0.70$)$. Although $\mathrm{h}_{\mathrm{m}}$ was proposed as different functions of time causing different increasing trends, better good fitness for the time-increasing $h_{m}$ was revealed because of the increasing trends almost presenting linear increases during the short observation time. Furthermore, the incomplete-mixing model revealed a better prediction than complete-mixing model by the studies of Yang et al. [3, 32], but the incomplete-mixing model considers too much extra parameters inversely estimated by the model and the complete-mixing model is more popular because of the simplicity [32]. Analogously, the timeincreasing $h_{m}$ proposed in this study neglected extra coefficient and the logarithmic function as time was more closed to transformation as indicated by Ahuja [19].

\section{Conclusion}

Concentrations of $\mathrm{NH}_{4}-\mathrm{N}$ and $\mathrm{TN}$ in overland flow presented large deviations in response to various RIs and SGs. In contrast, $\mathrm{NO}_{3}-\mathrm{N}$ concentration for 12 treatments all highly declined from the initiation of runoff and then stabilized with slight deviations. The effective mixing model was adopted and refined to simulate $\mathrm{NH}_{4}-\mathrm{N}$, $\mathrm{NO}_{3}-\mathrm{N}$ and $\mathrm{TN}$ transfer from purple soil to overland flow. The mixing depth, $h_{m}$, was a critical factor for chemical transport from soil. The time-averaged $\mathrm{h}_{\mathrm{m}}$ correlated positively with RIs but negatively with SGs. The time-increasing $h_{m}$ in the refined model increased on the basis of a certain initial depth. The linear regressions between simulated results and experimental data indicated that (1) the predictions for $\mathrm{NO}_{3}-\mathrm{N}$ transfer from soil to overland flow were significantly better than $\mathrm{NH}_{4}-\mathrm{N}$ and $\mathrm{TN}$; (2) the model simulation results were much more likely to reveal goodness of fit subjected to the low RIs; and (3) the refined model with a time-increasing $h_{m}$ showed refinements from the effective mixing model. Consequently, we attribute the differences in model simulation with nitrogen type and rainfall related to observed transfer dynamics, sorption and volatilization, and mixing magnitude.

Given our findings, we suggest that a time-increasing effective mixing depth is reassessed in the improvement of nitrogen transfer modelling. We also believe that the dynamics of $\mathrm{NH}_{4}-\mathrm{N}$ and $\mathrm{TN}$ transfer in runoff need to be examined further by experimental and modelling approaches.

\section{Acknowledgements}

This research was supported by the Changjiang River Scientifc Research Institute and was founded by the National Natural Science Foundation of China (grant No. 51879071), the Fundamental Research Funds for Central Universities (grant No. 2018B627X14), the Ministry of Education, China - 111 Project (grant No. B17015), the Postgraduate Research and Practice Innovation Program of Jiangsu Province (grant No. KYCX18_0596), Priority Academic Program Development of Jiangsu Higher Education Institutions (PAPD) (grant No. YS11001 and sys1103), and the Water Resource Science Project of Jiangxi Province (grant No. KT201507)

\section{Conflict of Interest}

The authors declare no conflict of interest.

\section{References}

1. WANG Q., WANG H. Analysis on the feature of effective mixing depth model for soil solute transporting with surface runoff on loess slope. J. Hydraul. Eng. 41 (06), 671, 2010 [In Chinese].

2. DONG W., WANG Q., ZHOU B., SHAN Y. A simple model for the transport of soil-dissolved chemicals in runoff by raindrops. Catena 101, 129, 2013.

3. YANG T., WANG Q., LIU Y., ZHANG P., WU L. A comparison of mathematical models for chemical transfer from soil to surface runoff with the impact of rain. Catena 137, 191, 2016.

4. OITA A., MALIK A., KANEMOTO K., GESCHKE A., NISHIJIMA S., LENZEN M. Substantial nitrogen pollution embedded in international trade. Nat. Geosci. 9 (2), 111, 2016.

5. ARMSTRONG A., QUINTON J.N., FRANCIS B., HENG, B.C.P., SANDER G.C. Controls over nutrient dynamics in overland flows on slopes representative of agricultural land in North West Europe. Geoderma 164 (1-2), 2, 2011.

6. MATYSIK M., ABSALON D., RUMAN M. Surface water quality in relation to land cover in agricultural catchments (Liswarta River Basin Case Study). Pol. J. Environ. Stud. 24 (1), 175, 2015. 
7. TREMBLAY N., BOUROUBI M.Y., VIGNEAULT P., BELEC C. Guidelines for in-season nitrogen application for maize (Zea mays L.) based on soil and terrain properties. Field Crop. Res. 122 (3), 273, 2011.

8. WU Y., ZHANG L., CHEN R., DENG L., FAN X. Reasearch on the effect of slope length and rainfall intensity on nitrogen loss in sloping land under artificially simulated rainfall. J. Soil Water Conserv. 31, 7, 2017 [In Chinese].

9. HOOGENDOORN C.J., LAMBERT M.G., DEVANTIER B.P., THEOBALD P.W., PARK Z.A. Nitrogen fertiliser application rates and nitrogen leaching in intensively managed sheep grazed hill country pastures in New Zealand. New Zeal. J. Agr. Res. 60 (2), 154, 2017.

10. QIAN J., ZHANG L., WANG W., LIU Q. Effects of vegetation cover and slope length on nitrogen and phosphorus loss from a sloping land under simulated rainfall. Pol. J. Environ. Stud. 23 (3), 835, 2014.

11. YUAN H., LIU E., PAN W., AN S. Water pollution characteristics and assessment in different functional zones. Pol. J. Environ. Stud. 23 (2), 541, 2014.

12. WANG Q., ZHAO G., TAO W., LIU Y., ZHANG P., CHAI, J. Mathematical model of soil nutrient along surface runoff under water scouring condition. Transact. Chinese Society Agricul. Machin. 189, 2016 [In Chinese].

13. SINGH V.P., WOOLHISER D.A. Mathematical modeling of watershed hydrology. J. Hydrol. Eng. 7 (4), 270, 2002.

14. JR D.A.S., BEYERLEIN D.C., JR D.H.H., CRAWFORD N.H. Agricultural runoff management (ARM) model. Version II: refinement and testing. 1977.

15. STEENHUIS T.S., WALTER M.F. Closed form solution for pesticide loss in runoff water. Transactions of the Asae 23 (3), 615, 1980.

16. AHUJA L.R., SHARPLEY A.N., YAMAMOTO M., MENZEL R.G. The depth of rainfall-runoff-soil interaction as determined by 32 P. Water Resour. Res. 17 (4), 969, 1981.

17. AHUJA L.R. Release of a soluble chemical from soil to runoff. 25, (4), 948-953, 1982.

18. AHUJA L.R., LEHMAN O.R. The extent and nature of rainfall-soil interaction in the release of soluble chemicals to runoff. J. Environ. Qual.; (United States) 12:1 (1), 34, 1983

19. AHUJA L.R. Characterization and Modeling of Chemical Transfer to Runoff. In: Stewart BA. editor Advances in soil science. 149, New York, 1986.

20. YANG T., WANG Q., WU L., ZHANG P., ZHAO G., LIU Y. A mathematical model for the transfer of soil solutes to runoff under water scouring. Sci. Total Environ. 569, 332, 2016.

21. PHILIP J.R. The theory of infiltration: 1 . The infiltration equation and its solution. Soil Sci. 83 (5), 1957.

22. SHARPLEY A.N. Depth of Surface Soil-runoff Interaction as Affected by Rainfall, Soil Slope, and Management. Soil Sci. Soc. Am. J. 49 (4), 1010, 1985.

23. INGRAM J.J., WOOLHISER D.A. Chemical transfer into overland flow. Symposium on Watershed Management. 2014.

24. YANG T., WANG Q., XU D., LV J. A method for estimating the interaction depth of surface soil with simulated rain. Catena 124, 109, 2015.

25. WALLACH R., JURY W.A., SPENCER W.F. The concept of convective mass transfer for prediction of surface-runoff pollution by soil surface applied chemicals. Transactions of the Asae 32 (3), 906, 1989.

26. TAO W., WU J., WANG Q. Mathematical model of sediment and solute transport along slope land in different rainfall pattern conditions. Sci. Rep.-Uk 7 (44082), 2017.

27. MOHAMMED D., KOHL R.A. Infiltration response to kinetic energy. Transactions of the ASAE - Am. Soc. Agri. Eng. (USA) 30 (1), 108, 1987.

28. BOTHMA C.B., RENSBURG L.D.V., ROUX P.A.L.L. Rainfall intensity and soil physical properties influence on infiltration and runoff under in-field rainwater harvesting conditions. Irrig. Drain. 61 (Supplement S2), 41, 2012.

29. MZEZEWA J., RENSBURG L.V. Effects of tillage on runoff from a bare clayey soil on a semi-arid ecotope in the Limpopo Province of South Africa. Water Sa 37 (2), 165, 2011.

30. ASSOULINE S. Rainfall-induced soil surface sealing. Vadose Zone J. 3 (2), 570, 2004.

31. XIE M., ZHANG Z., ZHANG P., HU B., XU J. Nitrogen loss as response to hydrological process of purple soil slopes under simulated rainfall. in submission, 2019.

32. YANG T., WANG Q., WU L., ZHAO G., LIU Y., ZHANG, P. A mathematical model for soil solute transfer into surface runoff as influenced by rainfall detachment. Sci. Total Environ. 557, 590, 2016.

33. WALLACH R., GRIGORIN G., RIVLIN J. A comprehensive mathematical model for transport of soil-dissolved chemicals by overland flow. J. Hydrol. 247 (1-2), 85, 2001. 